\title{
Content and analysis of professional development courses for teachers of higher education institutions
}

\author{
Pozilova Shakhnoza Khaydaraliyevna, \\ Doctor of Philosophy in Pedagogical Sciences (PhD), \\ Tashkent university of information technologies, Uzbekistan
}

\begin{abstract}
The article considered the problem of professional creativity of pedagogical staff of Higher Education institutions. Despite of these author analyzed system of professional development courses for teachers of higher education institutions.
\end{abstract}

Keywords: professional education system, pedagogical staff, professional creativity, development courses,

\section{Introduction}

The development of the world economy demonstrates the urgency of building the capacity of qualified professionals to develop scientific and technical processes, as well as their creative abilities, focusing on innovation in the training of teaching staff, along with active creative thinking and professional competence. In particular, the UNESCO Bridging Innovation and Learning in TVET (BLIT) ${ }^{1}$ project aims to develop the professional competence of teachers based on an inclusive approach to vocational education and peer learning ${ }^{2}$, improving the process of maturation. Prospects for further development of vocational education were identified at an official conference (Berlin, September 19, 2003) held by officials from the Ministries of Education of 29 European countries ${ }^{3}$.

The Resolution of the Cabinet of Ministers of the Republic of Uzbekistan "On radical improvement of the system of management and retraining and advanced training of teachers in the professional education system" is based on long-term goals and development of the system of advanced training and retraining based on the following requirements: - development of their skills in modern areas of scientific and practical research, technological development and innovations in the taught disciplines, as well as the organization of the educational process on the basis of continuous professional development; - High-performance modern education and innovative technologies, qualification requirements for management and retraining and continuous professional development of professional educational institutions with the widespread introduction of advanced foreign experience, continuous updating of curricula and programs, management of professional educational institutions and teaching staff organization and efficiency at the required level; - Acquisition of advanced pedagogy, information and communication and innovative technologies, the development of skills for their active application in the educational process, using the global Internet information network, multimedia systems and distance learning methods; - increase the level of practical mastery of a foreign language and its widespread use to constantly improve their professional skills, pedagogical and scientific activities; - Full implementation of indirect forms of professional development, the introduction of

\footnotetext{
${ }^{1}$ https://unevoc.unesco.org//bilt/BILT

${ }^{2} \mathrm{https} / / /$ intranet.ecu.edu.au/learning/curriculum-design/teaching-strategies/peer-learning

${ }^{3}$ Коммюнике конференции министров, ответственных за высшее образование, от 19 сентября 2003 г. // Правовое обеспечение образовательной деятельности: Сб. документов. Ч. І: Нормативные правовые и иные акты в области образовательной деятельности / Под ред. А.А. Шулуса. М.: АТиСО, 2008.
} 
alternative forms of professional development based on the development of differentiated continuous professional development processes, taking into account the results of scientific and scientificpedagogical activities of management and teaching staff ${ }^{4}$.

It is known that the main purpose of the system of management and retraining and professional development of teachers in the vocational education system is to have professional competence appropriate to the students of the labor market, responsible, skilled in their profession and able to operate in accordance with modern requirements. training of qualified personnel with social and professional mobility. Accordingly, in order to regularly improve the professional skills of teachers of vocational education, master classes and trainings on the development of the education system are organized in cooperation with national and foreign educational institutions. The refresher courses focus on writing and participating in scientific and applied research throughout the learning process, with the main goal being to develop innovations and new teaching methods in the subjects being taught and to develop skills to apply them in practice. The main requirements for the necessary and sufficient level of preparation for management activities, which are common to all categories of students, are: Knowledge and ability to apply the laws of the Republic of Uzbekistan "On Education", "On the National Training Program"; professional competence; have sufficient theoretical knowledge in their specialty and practical experience as a leader; leadership and organizational quality; spiritual and moral quality; responsibility, initiative and determination; objective monitoring and assessment of conditions; psychological preparation; be able to clearly define goals and objectives; social activity; Loyalty and patriotism; know the basics of labor law and law; basics of management and marketing in vocational education; knowledge of the use of communication technologies; understanding the nature and social significance of management activities; readiness for regular professional growth, acquisition of new knowledge; knowledge of the basics of management and entrepreneurship in the professional field; knowledge of the principles of spiritual, moral and educational work on the basis of the ideas of independence; decision-making, forecasting and evaluating the results of their decisions; knowledge of normative and legal documents related to the organization of secondary special, vocational education institutions and the organization of office work on their basis; conclusion of cooperation agreements with various state and social organizations; have the basics of colloquial speech in one of the foreign languages 5 .

The Resolution of the Cabinet of Ministers of the Republic of Uzbekistan "On measures to improve the system of teacher training for secondary special, vocational education institutions" The main directions of development of the system of training, retraining and advanced training of teachers of academic lyceums and professional colleges in 2001-2010 as follows: Ensuring continuous professional development and professional development of pedagogical staff of academic lyceums and professional colleges, as well as the teaching staff of higher education institutions involved in their training; introduction of advanced international pedagogical experience through the use of modern foreign methods in the teaching process and the expansion of internships in the leading educational centers of developed countries for teachers of higher education institutions engaged in training, retraining and advanced training of teachers of secondary special, vocational education; training of engineering and pedagogical staff by deepening their cooperation and cooperation with basic higher education institutions using the production potential of enterprises based on modern technologies; organization of regular attestation of heads and teachers of academic lyceums and professional colleges, at least once every three years. Filling vacancies of principals and teachers on a competitive basis; Introduction of the method of distance learning of teachers with the extensive use of modern

\footnotetext{
${ }^{4}$ Ўзбекистон Республикаси Вазирлар Махкамасининг “Профессионал таълим тизими бошқарув хамда педагог кадрларини қайта тайёрлаш ва уларнинг малакасини ошириш тизимини тубдан такомиллаштириш тўғрисидаги” Қарори (9.02.2020 й.)

${ }^{5}$ Профессионал таълим тизими рахбар кадрларининг малакасини ошириш мазмуни, сифати ва уларнинг тайёрланганлигига куйиладиган давлат талаблари.
} 
information technologies and the opportunities of the international information network Internet ${ }^{6}$

In order to implement these tasks in practice, one of the forms of professional development of teachers and engineers of professional colleges - the development of internships in educational and training centers of developed countries was continued. At the same time, special attention was paid to the organization of internships at the expense of the "Teacher" Fund and foreign grants and loans attracted for these purposes. Based on the experience of establishing and organizing training centers in foreign countries, base centers for the study of innovative methods of education in professional colleges have been established. Retraining and advanced training of teachers of general education was carried out in leading and basic universities in accordance with the needs of secondary special, vocational education institutions, and retraining and advanced training of special subjects and engineering and pedagogical staff - in specialized departments, faculties and centers of higher education. Remote retraining and professional development of teachers with the use of e-mail and the Internet has developed. The Ustoz Foundation was established in accordance with the Decree of the President of the Republic of Uzbekistan "On radical reform of the system of education and training, upbringing of a harmoniously developed generation" to train qualified teachers from educational institutions, vocational schools, is a non-profit charitable foundation, which aims to ensure that they learn from the positive experiences of education in developed countries, get acquainted with new pedagogical technologies of teaching and gain experience abroad. The fund conducts competitions to identify talented young teachers, develop their abilities, creative potential, improve their professional skills, gain experience in advanced educational institutions and centers of developed democracies, send teachers to advanced training in foreign educational institutions, improve their skills and gain experience abroad. - to monitor the educational process of teachers, as well as postgraduate work, to promote the effective use of their scientific and pedagogical potential, to establish awards of the Fund to accelerate the implementation of the National Training Program, to improve the skills of teachers, including sponsors, including , development of cooperation with international organizations and foundations, attracting investments of domestic and foreign investors in the training of highly qualified professors and teachers Adequate reforms have been carried out in the country, such as participation in international projects and programs in education, dissemination of best practices in the education system of developed democracies in the system of continuing education and training.

Researcher A.S.Djuraev in his dissertation "Improvement of pedagogical mechanisms of professional development of students in the process of professional development" as a basic concept of andragogic education in the process of professional development of students the content of acmeological motivation and the principles of integrity, integrity, self-development of the acmeological environment The socio-psychological (leadership, communicative) and intellectual (social, verbal, nonverbal intelligence) features of the professional development of the trainees of the refresher course are important to accelerate the interaction of the andragogic approach with the requirements of vitagen education. Improving the professional level of professional development on the basis of proving the empirical level and validity of the author's work developed on the basis of the matrix "Expert factor".

Problems of formation of the integrated electronic information-educational environment for systematization of educational and methodical information in retraining and advanced training of pedagogical staff are covered in the scientific work of T.T.Shoymardonov. In the context of the introduction of higher education institutions, ensuring the development of their creative potential

\footnotetext{
6 Ўзбекистон Республикаси Вазирлар Махкамасининг “Ўрта махсус, касб-хунар таълими муассасалари учун педагог кадрлар тайёрлаш тизимини такомиллаштириш чора-тадбирлари тўғрисида” ги Қарори (10.08.2012 й. 242-сон Қарори).

Джураев А.C. Малака ошириш жараёнида тингловчиларнинг касбий малакасини ривожлантиришнинг педагогик механизмларини такомиллаштириш: Пед.фанл.бўйича фалсафа доктори(PhD) ... дисс. автореф. - Сам.: 2019. - 8 б.
} 
through the full implementation of all forms of professional development of teachers is becoming a topical issue. ${ }^{8}$

According to the "Program of training, retraining and advanced training of teachers and engineersteachers of secondary special, vocational education system until 2010" at the initial stage of implementation of the national program of training teachers with higher education and retraining of teachers and their A two-tier system of a network of advanced training institutions has been established. This program provides for the deepening of the reform process based on the tasks of a qualitatively new stage in the implementation of the National Program of Personnel Training. The following tasks were performed to promote the quality of training and education of personnel for the sectors of the economy: 1. Taking into account the requirements of the system of secondary special, vocational education, developed flexible educational programs for training, retraining and advanced training of teachers. 2 . Strengthened the material and technical base of higher education institutions specializing in the training, retraining and advanced training of teachers and engineers-teachers.

3. The professional development of the teaching staff of higher education institutions, institutes, faculties and centers for retraining and advanced training of teachers and engineers-teachers, the study of foreign languages has been expanded.

4. An integrated (dual) system of vocational education with production was introduced for training, retraining and advanced training.

5. Advanced modern pedagogical technologies have been introduced into the process of professional development of teachers and engineering-pedagogical staff.

6. The following indicators, which provide pre-training, retraining and advanced training of teachers and pedagogical engineers, have been identified annually. According to statistics, during the commissioning of new and renovated secondary special, vocational education institutions, the absolute need for teachers and engineering-teaching staff in 2010 amounted to more than 167 thousand people. The need for pedagogical staff of 178 academic lyceums established by 2010 amounted to 8.4 thousand people, and the number of teachers required for 1689 vocational colleges increased to 158.8 thousand people. To meet the needs, by 2010 the volume of training of teachers and engineering-pedagogical staff for the system of secondary special, vocational education was increased every year. In order to fully provide academic lyceums and professional colleges with teachers, 101.2 thousand specialists have been trained over 10 years.

To date, the introduction of modern forms of vocational education and the constant updating of its content, continuous training of vocational education specialists, radical improvement of the quality of training, organization of the pedagogical process on the basis of new pedagogical forms and methods, innovative ideas, acmetechnologies application, improving the vocational training process is becoming one of the important and topical issues. The Asian Development Bank (ADB) has provided a \$ 57 million loan to Uzbekistan to equip 45 vocational colleges and lyceums, publish new textbooks and manuals, and improve the skills of teachers in secondary special and vocational education. This is evidenced by the Resolution of the Cabinet of Ministers of March 7, 2000 No 82 "On measures to implement the project" Development of secondary special, vocational education". ${ }^{9}$

Secondary special education staff - the implementation of a system of national standards for determining the level of professional competence of managers and teachers in education, the formation of a reserve of highly qualified personnel for senior positions in vocational education institutions using modern technologies of retraining and advanced training. introduction of a transparent organizational and legal mechanism based on the selection, recruitment and certification of teachers for continuous

\footnotetext{
8 Шоймардонов Т.Т. Педагог кадрлар малакасини ошириши ва касбий фаолияти мониторингини ташкил этишнинг электрон тизими: Пед.фанл.бўйича фалсафа доктори(PhD) ... дисс. автореф. - Т.: 2017. - 10 б.

9 Ўзбекистон Республикаси Вазирлар Махкамасининг «Ўрта махсус, касб-хунар таълимини ривожлантириш» лойихасини амалга ошириш чора-тадбирлари тўғрисида” ги 2000 йил 7 мартдаги 82-сон Қарори.
} 
professional development, development and effectiveness of research in retraining and advanced training institutions, attracting talented young teachers and the widespread implementation of research results in the education system indicates that it is evolving. A number of scientific studies aimed at developing the professional competencies of teachers of vocational education in the country. AR Khodjabaev developed the pedagogical basis of educational and methodical support of teachers of labor and vocational education and showed ways to apply them in practice. A number of factors and conditions that provide the process of formation and training of a teacher of vocational education have been identified and justified, the descriptions of the educational process as a system are also disclosed.

In the research of U.N.Nishonaliev, the process of training teachers of labor education has been studied in different historical periods and an innovative approach to the personality of teachers of vocational education has been studied.

The theoretical and methodological aspects of the training of teachers of vocational education and labor education are reflected in the fundamental research of R.Kh. Djuraev.

Socio-pedagogical and theoretical-methodological bases of development of secondary special, vocational education in Uzbekistan were studied by H.F. Rashidov.

U.I.Inoyatov scientifically substantiated the theoretical and organizational-methodological bases of control and management of the quality of education in vocational education institutions.

The fundamental research of B. Mirzakhmedov and KT Olimov studied the theoretical and practical aspects of the creation of textbooks for vocational education. In this fundamental research, the concept of creating a new generation of educational and methodological literature for the process of teacher training in vocational education is scientifically based and scientific and methodological recommendations for improving the quality of the educational process are given.

From the above analysis we can see that the organization of the training process in professional development courses for teachers of professional educational institutions, the analysis of modules in the educational process and the use of innovative technologies in research activities aimed at developing professional creativity in pedagogical activities. In accordance with the Decree of the President of the Republic of Uzbekistan dated September 6, 2019 No PF-5812 "On additional measures to further improve the system of vocational education" focused on:

development of their skills in modern areas of scientific and practical research, technological development and innovations in the taught disciplines, as well as the organization of the educational process on the basis of continuous professional development;

It is necessary to constantly update the qualification requirements, curricula and programs for the retraining and continuous professional development of management and teaching staff of professional educational institutions with the widespread introduction of high-performance modern education and innovative technologies, advanced foreign experience. level of organization and efficiency;

mastering advanced pedagogy, information and communication and innovative technologies using the global Internet information network, multimedia systems and distance learning methods, developing skills for their active application in the educational process;

to increase the level of practical mastery of a foreign language and its widespread use for the continuous improvement of their professional skills, pedagogical and scientific activities;

full implementation of indirect forms of professional development, introduction of alternative forms of professional development based on the development of differentiated continuous professional development processes, taking into account the results of scientific and scientific-pedagogical activities of management and teaching staff.

In accordance with this regulation: pedagogical staff of vocational education institutions heads of departments, teachers of general education and special subjects, masters of industrial education and others. Retraining course for teachers of vocational education institutions (retraining course) - is the acquisition of new professional knowledge, skills and abilities in educational programs designed to 
improve the quality of teaching and the needs of the labor market. Professional development course for management and teaching staff of professional educational institutions (professional development course) - new professional knowledge and skills, modern skills and the necessary and sufficient level for management and pedagogical activities and the quality required for the educational process in accordance with state educational standards defined as a form of postgraduate education that provides competencies. The process of continuous professional development of management and teaching staff of vocational education institutions includes:
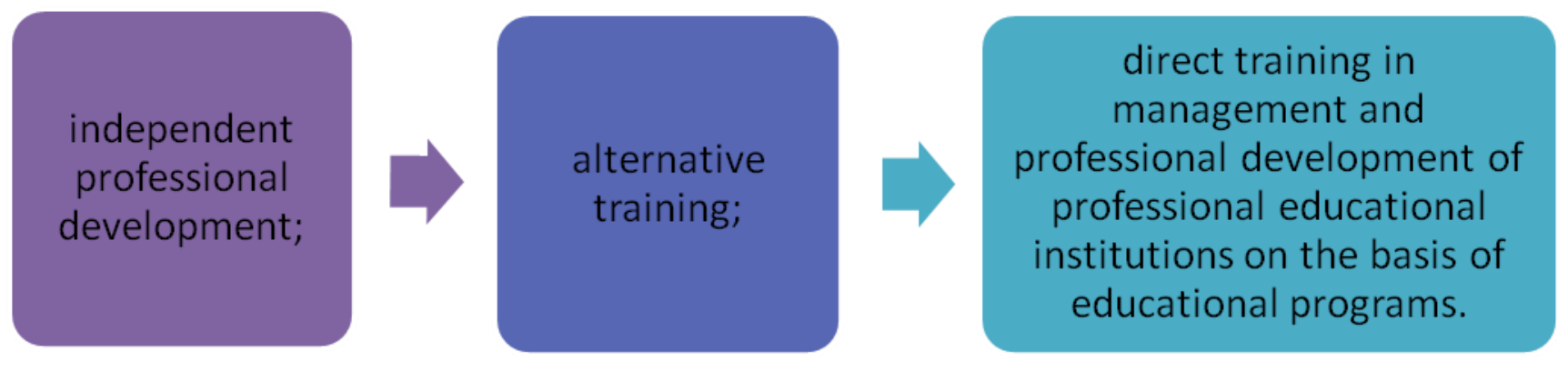

Indeed, in-service training courses show a greater approach to improving the professional creativity of teachers who are creative, pedagogical, experienced, innovative, authors of research papers. At the same time, it is determined that the activity of teachers who do not show the appropriate qualities in their pedagogical practice will be at the same level. In our view, the formation and improvement of individual psychological competence, professional-personal orientation at the level of content is important.

\section{Conclusion}

In our opinion, a number of complex tasks should be implemented in the system of professional development and retraining of vocational education staff of our country. These would include: - creating the necessary conditions for the professional development and personal orientation of the teacher; - to pay attention to the organizational and content aspects of advanced training and retraining in the modernization of education; - practical application of factors such as interactivity, continuity, continuity, design in a creative, individual approach to professional development; - take into account the best practices of teachers (including teachers in in-service training).

\section{References:}

1. Communique of the conference of ministers responsible for higher education, September 19, 2003 // Legal support of educational activities: Sat. documents. Part I: Normative legal and other acts in the field of educational activities / Ed. A.A. Shulus. M .: ATiSO, 2008.

2. Resolution of the Cabinet of Ministers of the Republic of Uzbekistan "On radical improvement of the system of management and retraining of teachers and their professional development" (February 9, 2020)

3. The state requirements for the content, quality and training of managers of the professional education system. 
4. Resolution of the Cabinet of Ministers of the Republic of Uzbekistan "On measures to improve the system of teacher training for secondary special, vocational education institutions" (Resolution No. 242 of 10.08.2012).

5. Resolution of the Cabinet of Ministers of the Republic of Uzbekistan No. 82 of March 7, 2000 "On measures to implement the project" Development of secondary special, vocational education ".

6. Juraev A.S. Improving the pedagogical mechanisms for the development of professional skills of students in the process of professional development: Doctor of Philosophy $(\mathrm{PhD}) \ldots$ diss. author's ref. - Sam .: 2019. - 8 p.

7. Shoimardonov T.T. Electronic system of organization of professional development and monitoring of professional activity of pedagogical staff: Doctor of Philosophy (PhD) ... dissertation. author's ref. - $\mathrm{T} .: 2017$. - $10 \mathrm{p}$.

8. Khodjaboev A.R. Uchebno-metodicheskiy kompleks podgotovki uchiteley trudovgo obucheniya. Method. recommendations. - T.:, UzNIIPI, 1989. - 93 p.

9. Nishonaliev U. Formation of personality of teachers of labor training: problems and perspectives. - T .: Fan, 1990. - 88 p.

10. Djuraev R.Kh. Organizational and pedagogical bases of intensification of the system of professional training in the educational institutions of professional education: Author. diss... dok.ped.nauk. $-\mathrm{T} .:$ 1995. -43 p.

11. Rashidov H.F. Features of the development of secondary special, professional education in Uzbekistan. - T .: Fan, 2004. - 288 p.

12. Inoyatov U.I. Theoretical and organizational-methodical bases of control of quality of education in professional college. Diss. Ph.D. ped. science. - Tashkent, 2003. - 327 p.

13. Mirzakhmedov BM, Olimov QT Problems of creating a new generation of educational literature on special subjects in the system of vocational education // Continuing education, 2004. - № 5. B. 22-26.

14. https://unevoc.unesco.org//bilt/BILT.

15. https://intranet.ecu.edu.au/learning/curriculum-design/teaching-strategies/peer-learning. 